JOURNAL of

CONTEMPORARY INDONESIAN

ART

Jurusan Seni Murni

FSR ISI Yogyakarta

ISSN: 2442-3394

E-ISSN: 2442-3637

\section{PUBLIC ART AND THE IMPACT IT HAS ON THE SOCIETY}

\author{
by: Hilary Adina Theresa Cuffie \\ Institution: Institut Seni Indonesia Yogyakarta \\ Jalan Parangtritis Km. 6,5 Sewon Yogyakarta \\ E-mail: dainacuffie1@gmail.com
}

\begin{abstract}
Public art is an art form that is displayed in public spaces; it's for everyone to enjoy. Its existence creates interests, entertainment, and beautifies the environment. Public art fulfills a variety of functions within the public sphere, providing opportunities for, artistic self-expression; community dialogue; education and enjoyment; inspiring participation in appreciation and creation of art; community problem solving; enhancement of the physical infrastructure and environment; and demarcation, celebration and transformation of places. This research aims to explore the impact public art has on the society. The literature review, document analysis and interview were done to help justify the findings of the investigation. The research found that there are multidimensional impacts of public art in urban environment(s). The perceived benefits of art that is displayed in public spaces either in physical, social, or cultural domains suggest that public art is very prominent in creating liveability and sustainability of the city.
\end{abstract}

Keywords: public art, environment, murals, society, literature

\begin{abstract}
Abstrak
Seni publik adalah bentuk seni yang ditampilkan di ruang publik; itu untuk dinikmati semua orang. Keberadaannya menciptakan minat, hiburan, dan memperindah lingkungan. Seni publik memenuhi berbagai fungsi dalam ruang publik, memberikan kesempatan untuk ekspresi diri artistik; dialog komunitas; pendidikan dan kesenangan; partisipasi yang menginspirasi dalam apresiasi dan penciptaan seni; pemecahan masalah masyarakat; peningkatan infrastruktur fisik dan lingkungan; dan demarkasi, perayaan dan transformasi tempat. Penelitian ini bertujuan untuk mengeksplorasi dampak seni publik terhadap masyarakat. Tinjauan pustaka, analisis dokumen dan wawancara dilakukan untuk membantu membenarkan temuan penyelidikan. Penelitian ini menemukan bahwa ada dampak multidimensi seni publik di lingkungan perkotaan. Manfaat yang dirasakan dari seni yang ditampilkan di ruang publik baik dalam ranah fisik, sosial, maupun budaya menunjukkan bahwa seni publik sangat menonjol dalam menciptakan liveability dan keberlanjutan kota.

Kata kunci: seni publik, lingkungan, mural, masyarakat, sastra
\end{abstract}




\section{A. Introduction}

Public Art can be aggressive, abstract, symbolic, decorative, and aesthetic. It is created by artists for different reasons. It can take a wide range of forms, sizes, and scales and can be temporary or permanent. It often interprets the history of the place, its people, and perhaps addresses a social or environmental issue. Public art can include murals, sculpture, memorials, integrated architectural or landscape architectural work, community art, digital new media, and even performances and festivals.

Since the late 1960s, work of contemporary art and craft have increasingly been located in city squares and on government builds, corporate plazas, parks and garden festivals', schools, hospitals, railway stations and on the external walls of houses, in a different visual language (Miles, 1997)

Public art instils meaning, a greater sense of identity and understandings of where we live, work, and visit, creating memorable experiences for all. It humanizes the built environment, provides an intersection between past, present, and future, and can help communities thrive. It allows spectators to physically engage with them. Public art is unique, exquisite, and one-of-a-kind.

Jack Becker the founder of Forecast Public Art, a 40 year old, non-profit organization; expresses in 2018 that "public art raise awareness of issues that are not talk about in ways that might incite action. Artists give voices to the unheard voices in our communities and it is completed by the audience in the public. We are all part of the public art ecosystem, we are all participants; public art doesn't work without the public. Public art is a solution to some of the problems and artists are creative problem solvers."

\section{B. Typology of public art}

a) Artwork of remembrance

Artworks of remembrance are used to commemorate an important historical figure or event of public significance. It can consist of figurative or abstract statues, monuments, memorials, and historical markers.

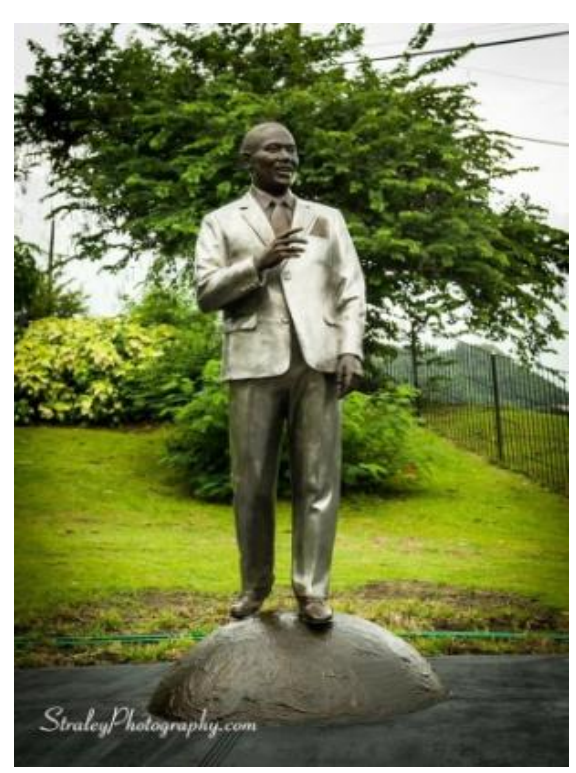

Public art as monument statues Artist: Maria McClafferty Medium: Bronze Year: 2017 Location: Grenada Photo: Micheal Straley 2017

b) Underwater sculpture

Underwater sculpture aim to create marine habitats that expand fishery populations and enhance sociocultural opportunities for the communities.

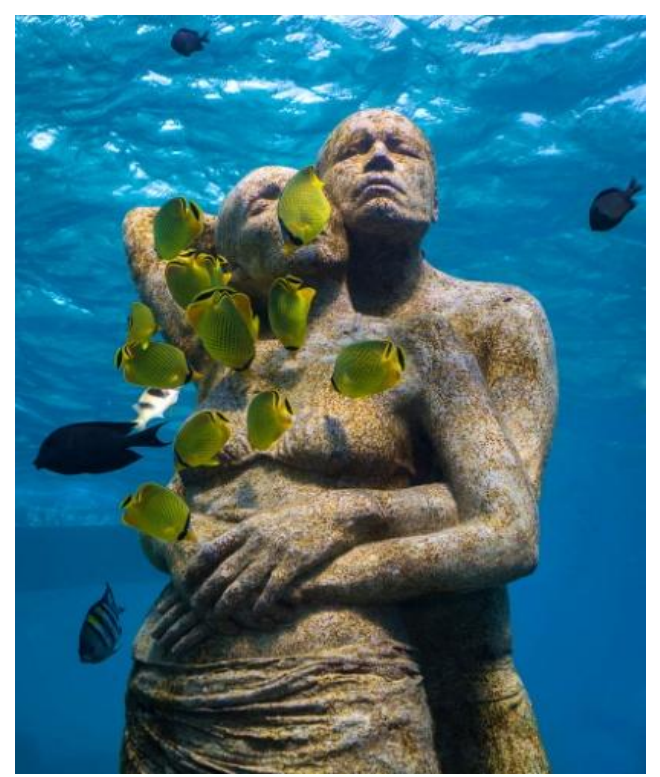

Effective public art

Artist: Artist: Jason deCaires Taylor Year: 2015

Location: Indonesia

Photo: Bask 2017

c) Festival Artwork

Festivals provide a platform to engage with large and diverse audiences. It 
imaginatively conveys the memory, traditions, customs, values, and aspirations of community members.

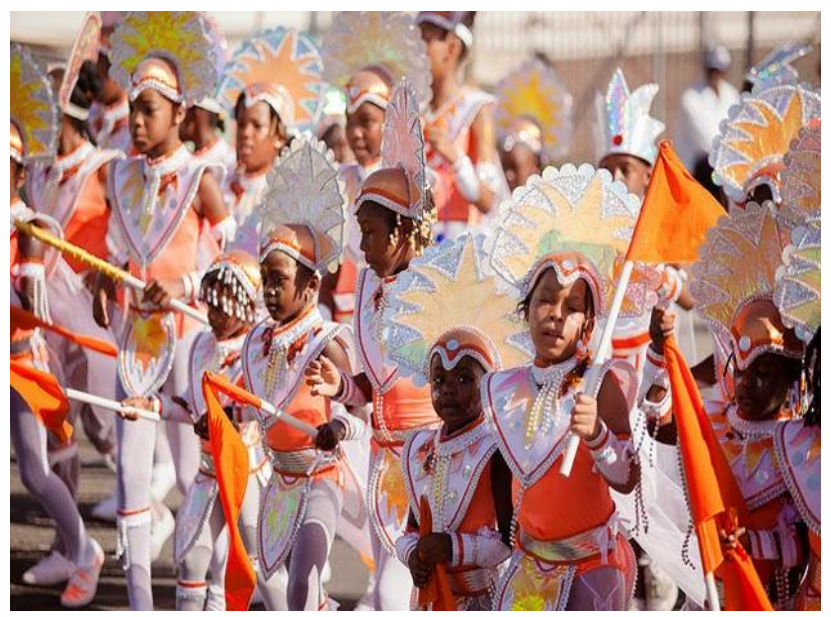

Public art as Festival Location: Trinidad \&Tobago Photo: Unknown

d) Technology-related artwork

Categories of public art have expanded with the evolution of technology. Technology related artwork is an electronic invention.

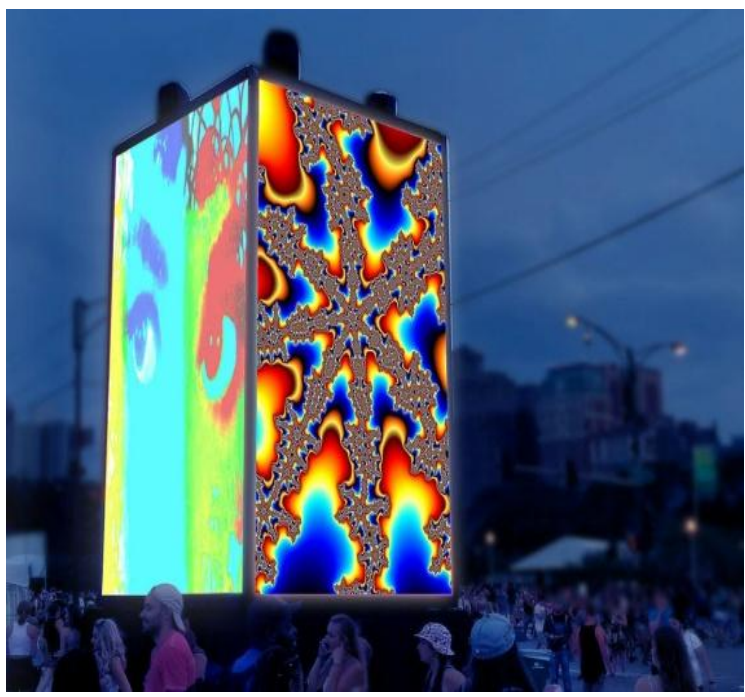

Public art as a digital display

Artist: Evan Levin \& Ashton Howard Location: Florida, USA Year: 2016

Photo: Unknown

e) Expressive artworks

Expressive artworks integrate objects into public spaces with the primary intention of introducing a sense of an artistic liveliness, playfulness, delight, and joy into the daily lives of the citizens.

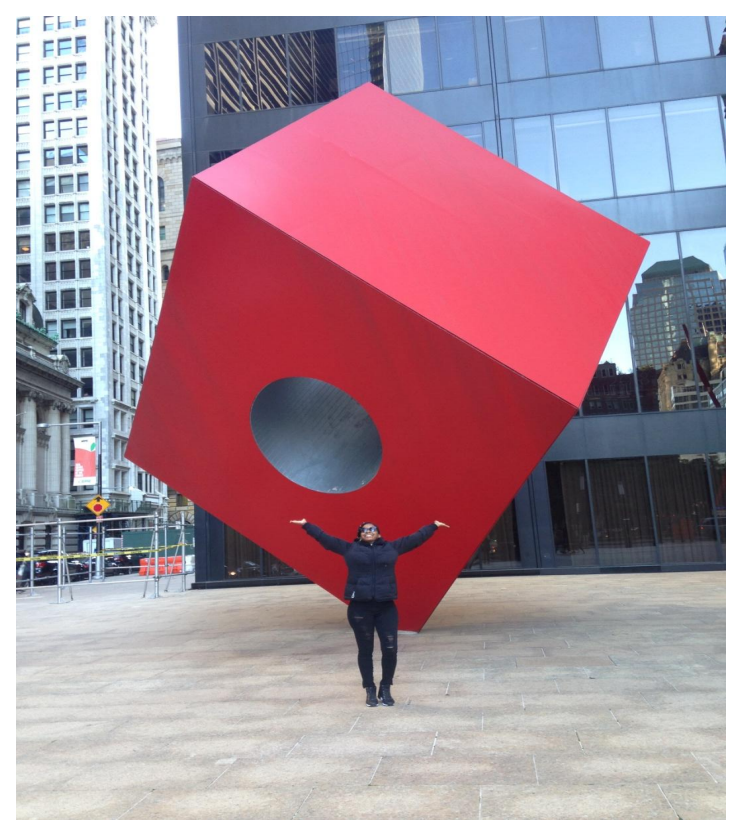

Public art as a Dice Artist: Isamu Noguchi's

Title: Red Cube Year: 1968

Location: Broadway Street, New York City Photo: Vadlyn Cuffie, 2020

f) Community Artwork

Community artworks engage the diverse communities by generating collaborations between professionals of visual arts and community members to attain works of artistic excellence.

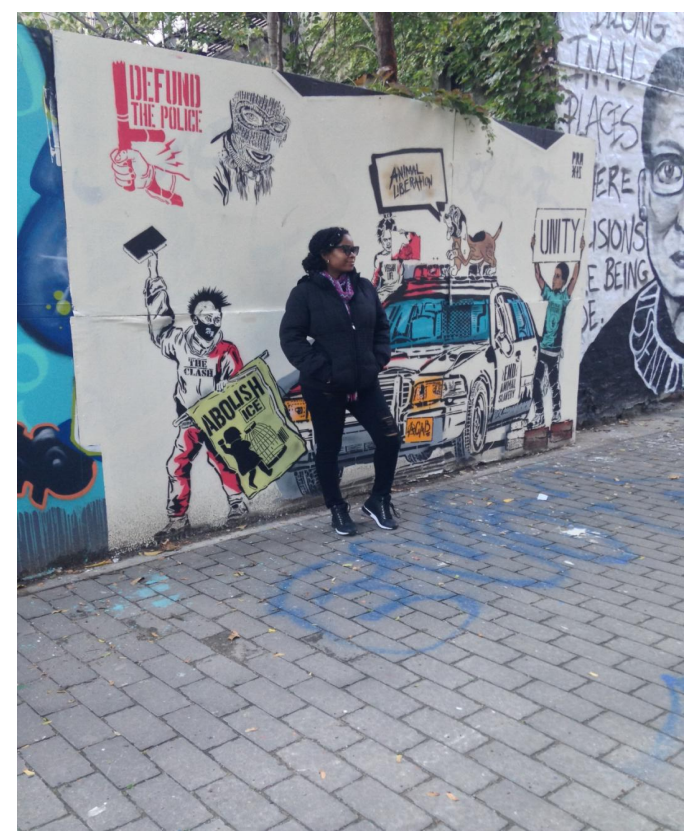




\author{
Public art as a mural \\ First Street Green Art Space \\ Location: 33 East 1st Street New York \\ Photo: Vadlyn Cuffie, 2020
}

(Source: Adapted from Portland Public Art Committee, 2009; Tyler, 2013; Nurul Izzah et al., 2014; Maria Trujillo 2019)

Art that has been displayed in the society has its purpose. It improved the quality of life in the environment. It has been established that public art plays important roles in the following manner (Hamilton City Council, 2010). identity.

Reflecting and expressing community's

1. Celebrating of significant people and places.

2. Telling the stories and histories of a place.

3. Contributing to a sense of pride and belonging to the community.

4. Improving the attractiveness of an area.

A similar list of perceived roles of public art presented by Mohd Fabian (2010), are as follows:

1. Celebrating the local event and history $\mathrm{x}$ Addressing community needs

2. Increasing aesthetical value $x$ Promoting a sense of community

3. Giving educational value to the community

Public art not only benefits the urban environment, but also the social and cultural benefits as well. Implementation of various forms of public art added significant value (historically, aesthetically and functionally) into the city and its community.

Art that has been displayed in the society has its purpose. It improved the quality of life in the environment. It has been established that public art plays important roles in the following manner (Hamilton City Council, 2010),

1. Reflecting and expressing community's identity.

2. Celebrating of significant people and places.

3. Telling the stories and histories of a place.

4. Contributing to a sense of pride and belonging to the community.
5. Improving the attractiveness of an area.

A similar list of perceived roles of public art presented by Mohd Fabian (2010), are as follows:

1. Celebrating the local event and history $\mathrm{x}$ Addressing community needs

2. Increasing aesthetical value $\mathrm{x}$ Promoting a sense of community

3. Giving educational value to the community.

Public art not only benefits the urban environment, but also the social and cultural benefits as well. Implementation of various forms of public art added significant value (historically, aesthetically and functionally) into the city and its community.

Table2. Purpose and form of public art

\begin{tabular}{|c|l|c|}
\hline $\begin{array}{l}\text { Public } \\
\text { art by } \\
\text { purpose }\end{array}$ & 3-D visual art & 2-D visual art \\
\hline $\begin{array}{c}\text { Aest } \\
\text { hetic }\end{array}$ & $\begin{array}{l}\text { Artistic } \\
\text { sculptures, } \\
\text { installation } \\
\text { arts } \\
\text { (permanent or } \\
\text { temporary) }\end{array}$ & $\begin{array}{l}\text { Murals, } \\
\text { graffiti art, } \\
\text { colored or } \\
\text { ornamental } \\
\text { pavement }\end{array}$ \\
\hline $\begin{array}{c}\text { Func } \\
\text { tional }\end{array}$ & $\begin{array}{l}\text { Street } \\
\text { furniture, } \\
\text { signage, bus } \\
\text { kiosks, bus } \\
\text { stops, street } \\
\text { light }\end{array}$ & $\begin{array}{l}\text { Pourister, map, } \\
\text { signage, } \\
\text { public } \\
\text { announceme } \\
\text { nt }\end{array}$ \\
\hline
\end{tabular}

Created by Muhammad Falihin Jasmi and Nik Hanita Nik Mohamad 2015

Although Table 2 provides clear distinction between different forms of public art, it frequently happens that selected visual art professional and community used the combination of forms and/or combination of different purposes (multipurpose) into their design and installation purpose.

Aesthetic and functional values of public art (Özsoy \& Bayram, 2007) there are three forms of public art; historical, aesthetic and functional. The historic public arts encourage the connection between the 
communities with their history and generate a collective memory; usually historical artworks are related to the famous figure or historical events. The aesthetic public arts are primarily responding to the aesthetic requirements or the beautification of a place as well to improve the visual quality. Mohd Fabian (2010) agreed that public art carries the fundamental impression of art that is to beautify spaces. There are also public arts that perform as functional objects which provide comfort and amenity in urban areas. For instance, street furniture, bus stops kiosks, vertical greenery, information boards, and signage (Jasmi \& Mohamad, 2016).

Although Table 2 provides clear distinction between different forms of public art, it frequently happens that selected visual art professional and community used the combination of forms and/or combination of different purposes (multipurpose) into their design and installation purpose.

\section{Method}

This paper reviews the impact of public in the society, mainly in the United States and the Caribbean region. The review of the public art projects is carried out as follows: Firstly, extensive review of the literature was conducted to gain information on the roles public art plays in the society. The literatures are from multiple sources including websites, brochures and trade magazines. These findings show why artists incorporate public art in the society and the positive impact it has. Those findings identify the types of public art installation. The identification based on the information obtained from reviews of the literature shown in Table 1; artworks of remembrance, expressive artworks, efficient artworks, community artworks, or technology-related artworks. Literature review was carried out to determine the significance of public art in the society towards improving quality of life.

\section{Discussion}

Public art is more than murals, monuments, and memorials. It is visible evidence of our shared humanity. One can tell a lot about a place by the kind of public art it has; it's like a cultural barometer or in some cases the absence of public art tells you something about the values of the community. Public art can be a process as well as a product, it can be visual, and it can be performative.

In 2009 artist Yvette Mattern used a whole city of Tulsa as her canvas showcasing her masterpiece "Global Rainbow" (figure 1) to help celebrate the opening of a new park on the riverfront in Tulsa.

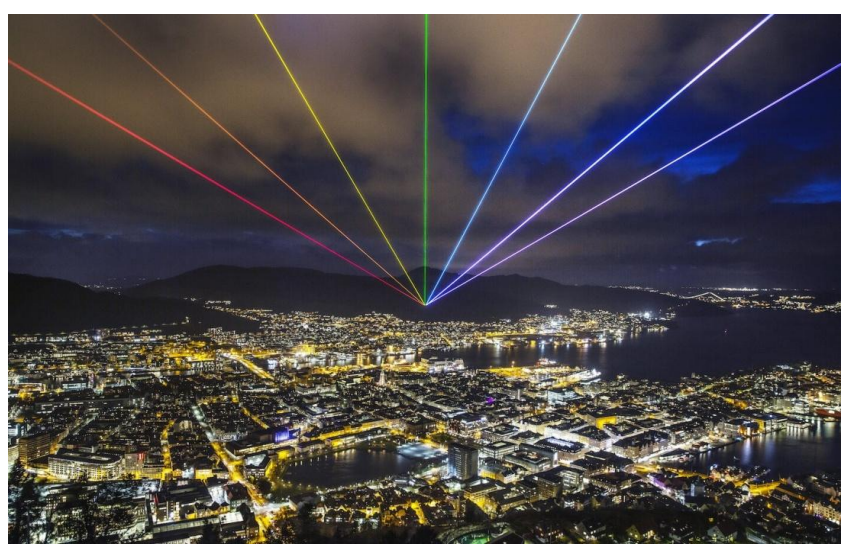

(Figure 1) Global Rainbow 2009: Artist Yvette Mattern, photo: James Ewing, 2009.

This artwork grabs the attention of people throughout Tulsa and as far as Oklahoma City. This spectacular art piece got people engaged in conversation. Yvette Mattern has found a voice in public art in a way that most artists might not think about. She is not a sculptor or a painter but she have a way of bringing the community together and giving a vision to a community, giving people something to talk about that takes their minds off some of the other things they're dealing with in the community.

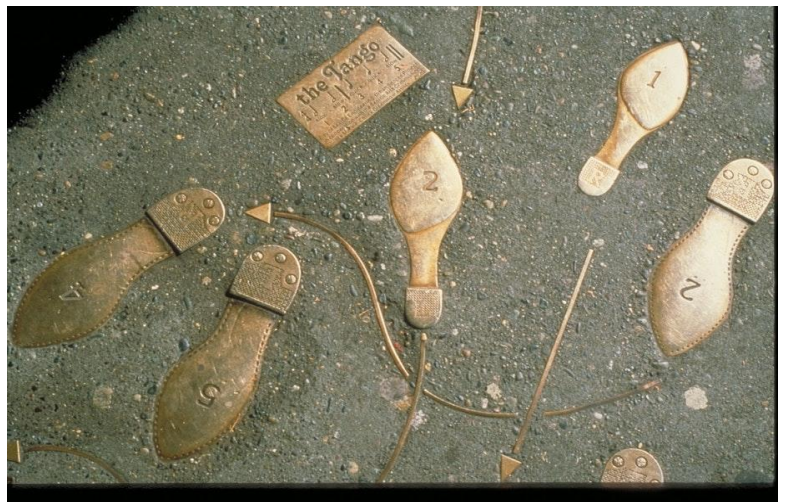

(Figure 2) Artist Jack Mackie's, 1979 Sculpture, Bronze (Photo: Courtesy Seattle office of Arts and Culture, 2014) 
Public art is not just art placed in a public space. It is believed to make contribution to contemporary urban issues for its participatory process and interactivity engaging the public. Artists create public art to help build communities and to make connections. Jack Mackie creates an incredible interactive series of dance instruction steps embedded in the sidewalks in Seattle (figure 2). People will come upon them and they will follow the dance steps. This artwork creates interaction and a fun experience between persons.

For example (figure 3), two strangers may come upon this dance instruction together; sharing this experience they might become friends for a lifetime. This is evident that even a small- scale public art project can change someone's life.

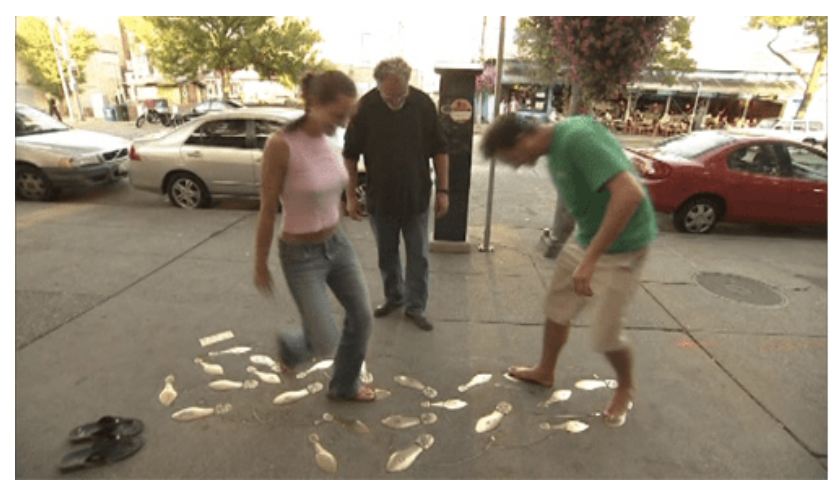

(figure 3) Dance Steps on Broadway Seattle, Washington, United States

Photo: Bootstrapper Studios, 2014

Sculptor and environmentalist Jason deCaires Taylor, use the ocean as his exhibition space. Over the past decade, Jason has built numerous large-scale underwater sculpture parks that contain over 850 life-sized works install all over the world. The $\mathrm{pH}$-neutral materials the artist uses to construct the parks make the sculptures habitable for marine life, demonstrating the definite impact art can have on an ecosystem. His 2016 work, "Raft of Lampedusa"(figure 4), ignites conversations about willful ignorance regarding climate change and the dangers that refugees face.Jason deCaires underwater sculpture aim to create marine habitats that expand fishery populations and enhance socio cultural opportunities for communities.

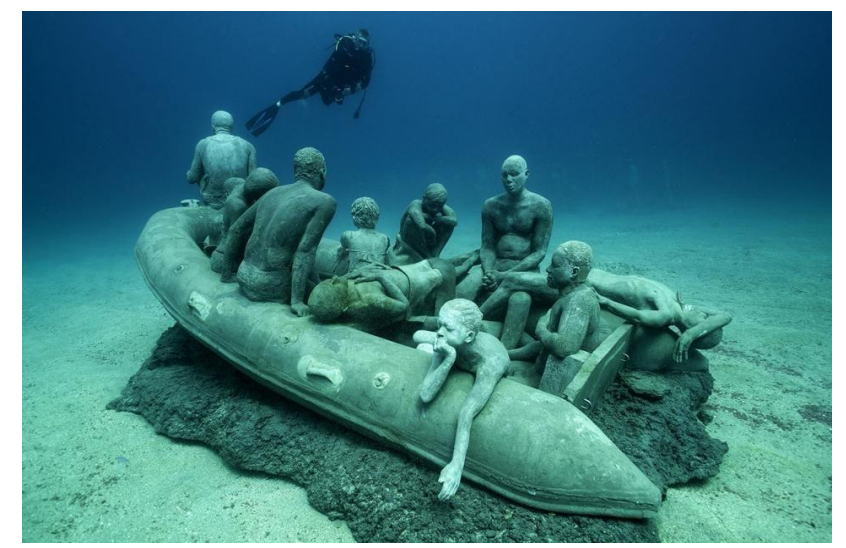

( Figure 4) Raft of Lampedusa, 2016, Artist: Jason deCaires Taylor's, underwater sculpture. Photo by Bask, 2016

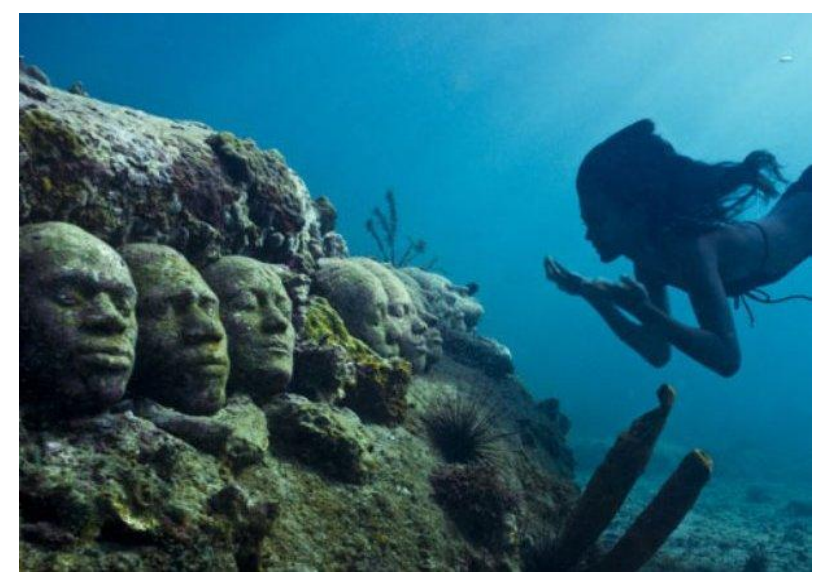

( Figure 5) Underwater sculpture, 2007 Artist: Jason deCaires Taylor Photo: Jason deCaires Taylor, 2009

Many of the sunken installations created by artists intended to raise awareness about polluted waters, dying coral reefs, and rising water temperatures. Other pieces tackle humanitarian issues, such as the refugee crisis and the perils of trans-ocean migration. Regardless of the artists' original intentions, the sculptures that wait for visitors beneath the salty water will soon become vessels for aquatic life that shelter millions of sea creatures (Maria Trujillo 2019).

The PangeaSeed foundation, an international movement empowering individuals to create meaningful environmental change for oceans; this foundation creates a public art program called Sea Walls.

Sea Walls bring the ocean into the streets by creating large-scalelarge-sale murals; educating and inspiring individuals and community through artivism. 
Jason Botkin, participant in the 'Blue Grenada' initiative. The 'Sea Walls: Murals for Oceans' project, attempt to connect local communities to ocean solutions through art work (figure 6).

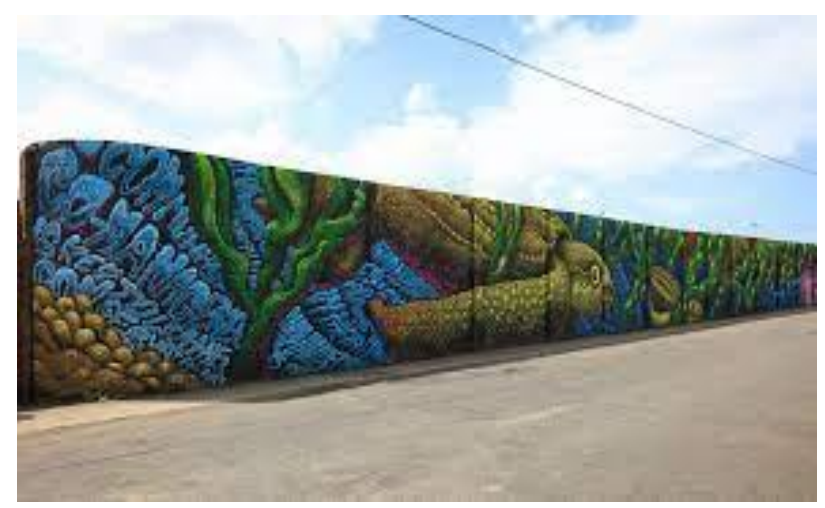

(Figure 6) Mural, Blue Grenada 2017 Artist Jason Botkin Photo: Tre Packard, 2017

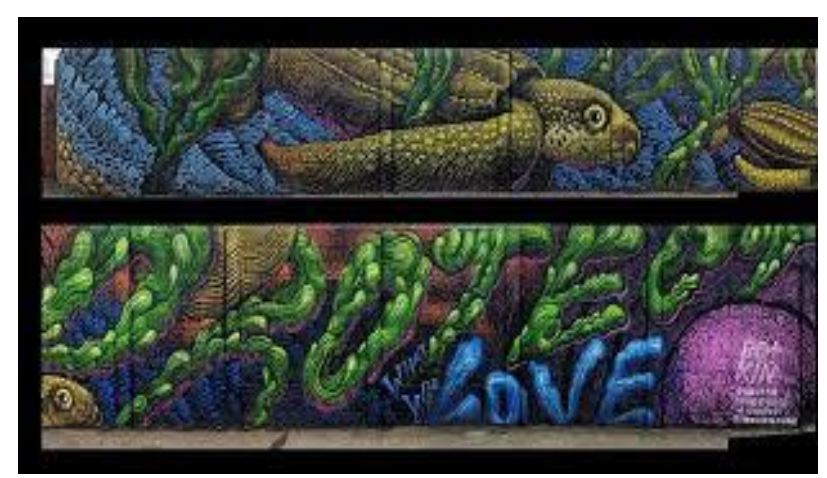

(Figure 7) Mural, Blue Grenada 2017 Artist Jason Botkin

Photo: Tre Packard, 2017

\section{E. Conclusion}

In conclusion the literature review shows that public art has improved the quality of life in the community. It does not only improved the attractiveness of an area, it also reflects the identity, commemorate the history and showcase the uniqueness of culture. Its contributions uplift the environment, improve the social characteristics, and elevate the standard of education.

Although public art is perceived to have a positivepositives impact on physical, social and cultural environments, it still needs further study either on its functional or artistic aspect; because there is still a risk that public art can cause another form of nuisance especially when it is located in inappropriate places and/or with poor artistic quality.

\section{F. References}

Jasmi, M. F., \& Mohamad, N. H. N. (2016). Roles of Public Art in Malaysian Urban Landscape towards Improving Quality of Life: Between Aesthetic and Functional Value. Procedia - Social and Behavioral Sciences, 222, 872-880. https://doi.org/10.1016/j.sbspro.2016 .05 .201

Miles, M. (1997). Art, Space, and The City: Public Art and Urban Futures. Routledge.

Özsoy, A., \& Bayram, B. (2007). The role of public art for improving the quality of public spaces in the residential environment. ENHR International Conference: Sustainable Urban Areas, Rotterdam, The Netherlands.

Portland Public Art Committee. (2009). City of Portland, maine guidelines for the public art ordinance. Page 3.

Tyler, J. (2013). Public art master plan, city of Coronado. Cultural Arts Commission.

Web:

Art work for change. (2012) Jason deCaires Taylor, from https://www.artworksforchange.org/p ortfolio/jason-decaires-taylor/

Alex Butler (2017) Lonely planet from, https://www.lonelyplanet.com/article s/bali-gili-meno-underwater-sculpture

Global RainbowYvette Mattern. (2009) from https://www.yvettemattern.com/globa 1-rainbow-info

Jseattle, Dance Steps. https://www.capitolhillseattle.com/20 14/10/filmmakers-seek-foxtrottingextras-for-broadway-dance-stepsshoot/

Creative Boom, 2009, digital magazine First American Art Magazine, quarterly magazine about indigenous art of the Americas, founded in 2013

https: / / www.artcritique.com/en/2019/06/underwater -sculptures-creating-life-andawareness / Maria Trujillo opinion 